International Research Journal of Microbiology (IRJM) (ISSN: 2141-5463) Vol. 6(3) pp. 042-045, December, 2015 Available online http://www.interesjournals.org/IRJM

DOI: http:/dx.doi.org/10.14303/irjm.2015.144

Copyright (c) 2015 International Research Journals

Review

\title{
Procalcitonin; appraisal of a useful tool for antimicrobial therapy-a chemical pathologist's perspective
}

\author{
Maxwell M. Nwegbu \\ Department of Chemical Pathology, College of Health Sciences, University of Abuja, Abuja- Nigeria \\ Corresponding author's E-mail:maxwellnwegbu@gmail.com
}

\begin{abstract}
Procalcitonin is a peptide with 116amino-acid sequence and precursor of the hormone calcitonin. It is an acute phase protein whose plasma level evaluation has found clinical application in the diagnosis of bacterial infections and consequently differentiation from viral infections. It has been shown to possess better diagnostic indices than other potential biomarkers in this regard such as $\mathrm{C}$-reactive protein. The afore mentioned utility of Procalcitonin (PCT) carries a lot of associated benefits which include reduction in misuse of antibiotics with the consequent outcome of antibiotic resistance, lesser cost of care, decrease in hospital stay and overall morbidity and mortality. Unlike in the developed world where it has found widespread utilization, PCT is yet to be applied in similar fashion in our country. Reasons for the above scenario have not been scientifically investigated and documented leaving just hypothetical assumptions. In this short review, I tried to speculate on the possible hypotheses.
\end{abstract}

Key words: Procalcitonin, Sepsis, Antibiotic Stewardship, Specificity, Sensitivity.

\section{INTRODUCTION}

Procalcitonin, a 116 amino acid peptide, is a member of the calcitonin (CT) super family of peptides (Schneider and Lam QT, 2007). It is encoded byCALC-1 gene which is transcribed in the presence of infection in nonneuroendocrine tissues. Ordinarily in the absence of infection, its transcription is constitutively suppressed except in the parafollicular (C) cells of the thyroid gland where it functions as the precursor peptide for the hormone calcitonin (Christ-Crain and Muller, 2007).

Studies have shown that PCT production increases exponentially following the release of certain inflammatory mediators and cytokines subsequent to bacterial infection (Gogos et al., 2000). A particular cytokine, interferon (INF)- $\mathrm{\gamma}$, has been shown to lessen this increased synthesis of PCT and the cytokine majorly plays its role following viral infections. As such viral infections are not associated with the aforementioned increase in PCT levels as seen in bacterial infections; this forms the basis of the utility of PCT to differentiatebetween bacterial and viral infections (ChristCrain and Muller, 2007; Linscheid et al., 2005)

The diagnosis of bacterial infections which are major causes of morbidity and mortality can be herculean. This is due to a number of factors such as long turnaround time for the bacteriologic culture assays, need for expertise and problems of low sensitivity and specificity associated with cultures of some body fluids (Uchil et al., 2011; Schuetz et al., 2011). Clinical practice has shown that early initiationof treatment for bacterial infections greatly improves outcomes. However for this to occur, easy and prompt recognition of these infections as distinct from viral infections or other causes of noninfectious inflammation is paramount.

Many biomarkers have been touted as potential indicators of bacterial infection or sepsis, but basically Creactive protein and PCT have gained widespread recognition (Simon et al., 2004; Joo et al., 2011). Studies have shown that C-reactive protein has lower sensitivity and specificity than PCT for diagnosis of sepsis. In addition PCT has the added advantage of a rapid rise, consistency in response following bacterial infections and rapid decline, on attenuation of the infectionconsequent on appropriate antimicrobial therapy (GiamarellosBourboulis et al., 2004). Findings also have revealed 
Nwegbu, 043

PCT as a prognostic indicator in bacterial infections (de Jager et al.,2009), which cannot be gotten from traditional parameters like white cell count.

\section{Benefits in antibiotic stewardship}

It is a well-documented fact that PCT is a good tool for guidance regarding antimicrobial therapy and therefore has priceless application in the reduction of misuse of antibiotics. Antibiotic misuse is a global problem and a study on acute respiratory infections showed that approximately $75 \%$ of all antibiotic doses are prescribed when such infections have a predominantly viral etiology (Christ-Crain and Muller, 2007; Evans et al., 2002).

PCT has also been applied as a tool to assess and commence discontinuation of antibiotic use or therapy especially in intensive care settings (Jacquot et al., 2009; Deis et al., 2010; Nobre et al., 2008). Sometimes decision on when to discontinue antibiotics can be a challenge and patients may have unnecessary prolongation of therapy due to absence of a reliable indicator of clearance of an infection. Reassessment using the traditional culture methods is ineffective due to the time-consuming nature of the process, difficulty in assessment in the presence of ongoing antibiotic use and lack of the sensitivity required to explicitlysignify the attenuation of sepsis etc.

On the other hand, a decrease in PCT levels, given the latter's high negative predictive value, is an indicator of successful antibiotic therapy (Schuetz et al., 2011).

It is a deducible fact that the twin factors of early antibiotic introduction and early discontinuation of antibiotic therapyfollowing therapeutic success will lead to a shortened hospital stay. These are two factors that PCT has been proven to modulate and as such is a tool to achieve decreased patient hospital stay and this has been validated by research findings (Bouadma et al., 2010).

An unassailable outcome of appropriate use of antibiotics is a reduction in the incidence of antibiotic resistance. This benefit has been clearly demonstrated by the use of PCT. The health and economic implications of increase in antibiotic resistant organisms arising from indiscriminate use of antibiotics is well known (Kristoffersen et al., 2009; Wenzel and Wong 1999).

A major cumulative benefit accruable from the aforementioned uses of PCT is reduction in the economic burden on patients in the treatment of infections. There is a currentpush in most advanced nations towards economic evaluation in terms of healthcare delivery of which drug cost is a major component (Burkhardt et al., 2010). This is a very important factor that should be in the front-burner especially in resource-poor settings. It is even more critical in our environment where majority of the populace are not covered under any form of health insurance and source treatment "out of pocket".

\section{Experience in our environment}

Plasma PCT evaluation has found widespread application in the diagnosis and management of patients in many clinical scenarios such astransplantation medicine, organ failure, severe injury in addition to bacterial infections in Europe (Jacquot et al., 2009; Florence, 2003; Madershahian et al., 2008; Yukioka et al.,2001). This is in contrast to our environment where it is seldom applied in clinical practice. Undocumented findings show that in the few centers, usually tertiary level care institutions, where PCT is used for diagnosis of sepsis, it was instituted oftentimes, as part of ongoing grant-funded research. Since there are no studies on this, only postulations can be advanced on the reasons for this. Could it be limited knowledge on the part of the clinicians and/or lack of clarity on who should initiate the introduction - medical microbiologist, the chemical pathologist or the clinicians? This hypothetical postulation on limitation in knowledge by the clinicians could span from little knowledge about its utility to not knowing whether their hospital laboratories can undertake PCTanalysis. Irrespective of the shortcomings involving the clinician in virtually nil PCT application in clinical practice in our environment, there is no gainsaying the fact that guidance needs to be provided by the laboratory physician for the clinician to make informed decisions.

Could it be that the laboratory physician is in limbo as to who should "bell the cat"? Maybe the microbiologist sees it as a biochemical analytical toolgiven the fact that it is a biomarker which is more in the domain of clinical chemistry and is commonly domiciled in clinical chemistry analyzer menu lists and not in microbiological analyzers! Or could it be the usual penchant to hold onto traditional methods?

There is no doubt that the chemical pathologist probably has the richest repertoire of information about PCT and knows about its potential utility. But is it that he/she sees its application in sepsis and other infectious conditions as venturing into an area that traditionally belongs to other disciplines? Maybe to the traditional clinical chemist in our environment, diagnosis of infection is an uncharted territory and should remain in the domain of the microbiologist as has been the case!

Meanwhile, if there is any part of the world that should benefit most from this tool, it is resource poor settings like ours where factors like poor antibiotic adherence due to cost, drug misuse with potential for increased antibiotic resistance is high, poor laboratory services for effective diagnosis of infections, high prevalence of communicable diseases, etc. are rampant.

There is no doubt however, that the laboratory physician, be it the chemical pathologist or medical microbiologist should take the initiative in this situation, beingthe interface between the laboratory and the bedside. Introduction of new tests is the responsibility of the laboratory physician and he determines the medical 
cut-offs and other decision limits that other physicians will reference in clinical decision making.

\section{Limitations of PCT in infection management}

Though the utility of PCT in bacterial infection management is well documented, some limitations in this application do exist. Clinical conditions wherein unspecific increases in plasma PCT levels occur in the absence of bacterial infection have been noted. Included amongst these clinical disorders is severe stress for example after severe trauma and surgery, cardiac shock, Addisonian crisis, stem cell transplantation, T-cell antibody and anti-thymocyte globulin therapy.etc. (Wanner et al., 2000' Uzzan et al., 2006; Hunziker et al., 2010; Schuetz et al., 2010; Brodska et al., 2009; Schumm et al., 2010).

Another challenge with PCT application in clinical practiceespecially in the setting of infections is the absence of widely acceptable reference intervals. This is particularly of import in our environment where there are no available reference intervals, bearing in mind documented findings that PCT levels are influenced by ethnicity (Uchil et al., 2011). This is further worsened by the lack of consensus, even in developed countries where PCT is being widely utilized, on the cutoff points of plasma PCT levels and the accompanying time intervals to use as benchmarks for determination of antibiotic response (Dolatabadi et al., 2015).

\section{CONCLUSION}

Procalcitonin is unarguably a valuable tool in the management of microbial infections and has ancillary benefits in many aspects of overall patient care and management. Laboratory support which is vital in infectious disease management needs to embrace this tool in our environment, for the benefit of the total healthcare delivery process. While some may want to highlight its few limitations in terms of lack of specificity in conditions like organ transplantation, adrenal failure etc, I will rather say that in our environment those conditions pale in significance when juxtaposed with sepsis cum bacterial infections.

\section{REFERENCES}

Bouadma L, Luyt CE, Tubach F, Cracco C, Alvarez A, Schwebel C, Schortgen F, Lasocki S, Veber B, Dehoux M, Bernard M, Pasquet B, Régnier B, Brun-Buisson C, Chastre J, Wolff M (2010). PRORATA trial group: Use of procalcitonin to reduce patients' exposure to antibiotics in intensive care units (PRORATA trial): a multicentrerandomised controlled trial. Lancet. 375:463-474

Brodska H, Drabek T, Malickova K (2009). Marked increase of procalcitonin after the administration of anti-thymocyte globulin in patients before hematopoietic stem cell transplantation does not indicate sepsis: A prospective study. Crit Care.;13:R37.
Burkhardt O, Ewig S, Haagen U , Giersdorf S , Hartmann O , Wegscheider K , Hummers-Pradier E , Welte T (2010). Procalcitonin guidance and reduction of antibiotic use in acute respiratory tract infection. EurRespir J.; 36: 601-607.

Christ-Crain M, Muller B (2007). Biomarkers in respiratory tract infections: Diagnostic guides to antibiotic prescription prognostic markers and mediators. EurRespir J.;30:556-573.

de Jager CP, de Wit NC, Weers-Pothoff G (2009). Procalcitonin kinetics in Legionellapneumophila pneumonia. ClinMicrobiol Infect:;15:1020-1025.

Deis J N, Creech C B, Estrada C M, Abramo T J (2010). Procalcitonin as a marker of severe bacterial infection in children in the emergency depart. Pediatr Emerg Care. ;26(1):51-60.

Dolatabadi AA, Memary E, Amin A, Shojaee M, Abdalvand A, Hatamabadi HR (2015). Efficacy of measuring procalcitonin levels in determination of prognosis and early diagnosis of bacterial resistance in sepsis. Niger Med J.; 17-22

Evans AT, Husain S, Durairaj L, Sadowski LS, Charles-Damte M, Wang $Y$ (2002). Azithromycin for acute bronchitis: a randomised, doubleblind, controlled trial. Lancet, 359:1648-1654.

Florence R (2003). An Introduction to Health Economics. Pharm J; 271: 679-681.

Giamarellos-Bourboulis EJ, Giannopoulou P, Grecka P, Voros D, Mandragos K, Giamarellou H (2004). Should procalcitonin be introduced in the diagnostic criteria for the systemic inflammatory response syndrome and sepsis? J Crit Care.;19:152-7.

Gogos CA, Drosou E, Bassaris HP, Skoutelis A (2000). Pro- versus anti-inflammatory cytokine profile in patients with severe sepsis: a marker for prognosis and future therapeutic options. J Infect Dis., 181: 176-180.

Hunziker S, Hugle T, Schuchardt K, Groeschl I, Schuetz P, Mueller B, Dick W, Eriksson U, Trampuz A (2010). The value of serum procalcitonin level for differentiation of infectious from noninfectious causes of fever after orthopaedic surgery. J Bone Joint Surg Am.; 92:138-148.

Jacquot A, Labaune JM, Baum TP, Putet G, Picaud JC (2009). Rapid quantitative procalcitonin measurement to diagnose nosocomial infections in newborn infants. Arch Dis Child Fetal Neonatal Ed.;94:F345-F348.

Joo K, Park W, Lim MJ, Kwon SR, Yoon J (2011). Serum Procalcitonin for Differentiating Bacterial Infection from Disease Flares in Patients with Autoimmune Diseases. J. Korean Med. Sci.; 26, 1147-1151.

Kristoffersen KB, Søgaard OS, Wejse C (2009). Antibiotic treatment interruption of suspected lower respiratory tract infections based on a single procalcitonin measurement at hospital admission-A randomized trial. ClinMicrobiol Infect. ;15:481-487.

Linscheid P, Seboek D, Zulewski H, Keller U, Muller B (2005). Autocrine/paracrine role of inflammation-mediated calcitonin generelated peptide and adrenomedullin expression in human adipose tissue. Endocrinology., 146: 2699-2708.

Madershahian N, Wittwer T, Strauch J (2008). Kinetic of procalcitonin in the early postoperative course following heart transplantation. $J$ Card Surg:;23:468-473.

Nobre V, Harbarth S, Graf JD, Rohner P, Pugin J (2008). Use of procalcitonin to shorten antibiotic treatment duration in septic patients: a randomized trial. Am J RespirCrit Care Med., 177:498505.

Schneider HG, Lam QT (2007). Procalcitonin for the clinical laboratory: A review. Pathology:;39:383-390.

Schuetz P, Albrich W, Mueller B (2011). Procalcitonin for diagnosis of infection and guide to antibiotic decisions: past, present and future. BMC Med. 9:107.

Schuetz P, Affolter B, Hunziker S, Winterhalder C, Fischer M, Balestra GM, Hunziker P, Marsch S (2010). Serum procalcitonin, C-reactive protein and white blood cell levels following hypothermia after cardiac arrest: a retrospective cohort study. Eur J Clin Invest, 40:376-381.

Schumm J, Pfeifer R, Ferrari M (2010). An unusual case of progressive shock and highly elevated procalcitonin level. Am J Crit Care.; 19(1):92-96.

Simon L, Gauvin F, Amre D, Saint-Louis P, Lacroix J (2004). Serum Procalcitonin and C-Reactive Protein Levels as Markers of Bacterial 
Infection: A Systematic Review and Meta-Analysis. Clinical Infectious Diseases.; 39, 206-217.

Uchil S, Ravi K V, Thimmaiah A K, Medha Y R, Punith K (2011). Significance of serum procalcitonin in sepsis.Indian $\mathrm{J}$ Crit Care Med.; 15(1): 1-5.

Uzzan B, Cohen R, Nicolas P, Cucherat M, Perret GY (2006). Procalcitonin as a diagnostic test for sepsis in critically ill adults and after surgery or trauma: a systematic review and meta-analysis. Crit Care Med., 34:1996-2003.
Wanner GA, Keel M, Steckholzer U, Beier W, Stocker R, Ertel W (2000). Relationship between procalcitonin plasma levels and severity of injury, sepsis, organ failure, and mortality in injured patients. Crit Care Med.;28:950-7.

Wenzel RP, Wong MT (1999). Managing antibiotic use-impact of infection control. Clin Infect Dis.;28:1126-1127

Yukioka H, Yoshida G, Kurita S, Kato N (2001). Plasma procalcitonin in sepsis and organ failure. Ann Acad Med Singapore;30:528-31 